Journal of Teacher Education for Sustainability

vol. 11, no. 1, pp. 86-96, 2009

\title{
DEVELOPMENT OF CREATIVE ACTIVITY OF PROSPECTIVE VISUAL ART TEACHERS
}

\author{
Aleksandra Šḷahova and Māris Čačka \\ Daugavpils University, Latvia
}

\begin{abstract}
The main task of training secondary school visual art teachers is to develop intelligent, socially active and creative individualities graced by knowledge and skills in pedagogy, psychology and art, as well as by abilities for self-development and self-education. These teachers need well-developed teaching skills and competence, proficiency in promoting their students' acquisition of artistic knowledge and competence in modern art. Besides, they should be able to creatively deal with unusual artistic tasks and to respond to the changes in contemporary art and culture, since alongside the teacher's qualification, these teachers are conferred the Bachelor Degree in Art. Therefore, creative study work is one of the significant stages in the development of professional skills for the prospective secondary school visual art teachers. In order to accomplish the tasks set, the work of the teacher educators should be directed towards the development of student's creative activity, so that they can independently and regularly develop their creative skills. The aim of the study has been stated to work out and theoretically substantiate the model of creative process aimed at facilitation of prospective secondary education art teachers' creative activity.
\end{abstract} Key words: prospective visual art teachers; creativity; creative activity; model of creative process.

\section{Creative personality and development of creative activity}

The UNESCO report on the perspectives of higher education in the 21st century underlines the fact that the rapid changes in the contemporary world require a new approach to the role of higher education. It should focus on students who will be the creators of social consciousness in future. The importance of young people's creative activity for emancipated life in a multicultural society is emphasized in the report, too. In this connection the necessity to make conceptual changes in higher education (including the professional higher art education) and to encourage innovations in pedagogy and didactics are mentioned (UNESCO, 1998).

Education has to give a student an opportunity not only to survive, but also to develop the self considering the goal of sustainability: "The sustainability has the specific dimensions; the content and interaction of these dimensions show the societal necessity 
of the flexible reaction toward the changes in the development of humanity and nature, education and science, human consciousness and activities for sustainability" (Salite, Mičule, Kravale, Iliško, \& Stakle, 2007, p. 289).

The daily routine of the students enrolled on the secondary school visual art teacher's programme is inconceivable without the continuous presence of creative activity. It is necessary for accomplishing the academic study tasks at university and unassisted creative art works done at home and in studios. To achieve profound and consistent results, creative activity has to become part of students' life, and the development of creative personality is necessary for this matter. Creative individuality is objective and unique wealth of the society. It is free and independent, rich in initiative, morally balanced, harmoniously (aesthetically, morally and intellectually in particular) developed, creatively capable being (Hibnere, 1998). In his recent article Mumford describes the requirements for creative people:

Creative people must be able to generate the likely downstream consequences implied by a new idea; they must be able to project other's reactions to an idea; they must be able to identify the resources needed for idea implementation; they must be capable of forming viable, perhaps somewhat opportunistic, plans for implementing these ideas; they must be able to identify significant problems emerging during implementation; and they must be able to adjust their initial plan, or approach, to take those implementation issues into account, considering both immediate and long-term objectives (Mumford, 2003, p. 116).

Summarizing various studies carried out by scholars in Latvia, Russia and other countries, it is possible to identify the following qualities of a creative personality (James \& Asmus, 2000-2001; Ikere, 2008; Glück, Ernst, \& Unger, 2002; Mumford, 2003; Sawyer, 2006; Вишнякова, 1995; Кривцун, 1997; Тюрин, 2001):

- receptiveness to new specific knowledge and experience;

- inquisitiveness;

- flexible thinking;

- appreciation of novelty and originality;

- broad interests;

- disposition for self-realization;

- ability to view the problem "from afar";

- intuition and intense feelings;

- ability to develop a viable idea, persistence, dynamic advancement and devotion to the problem solution;

- certainty about the correctness of one's judgement, readiness to take risks;

- tolerance to ambiguity;

- independence and self-dependence;

- aesthetic feelings, aspiration to the beautiful.

Many scholars consider that any person can be creatively active (Tan, 2004; Varzim, 2005 ), it is just necessary to reveal and develop the creative potential of personality.

According to Sawyer (2006), creativity can be characterized by contrasting what it is not and what it is:

- Creativity is not a special mental process, but involves everyday cognitive process. 
- Creativity is not a distinct personality trait; rather it results from a complex combination of more basic mental capabilities.

- Creativity does not occur in a magical moment of insight; rather creative products result from long periods of hard work that involve many small miniinsights that are organized and combined by the conscious mind of the creator.

- Creativity is always specific to a domain. No one can be creative until they internalize the symbols, conventions, and languages of a creative domain (p. 74).

However, even very creative personalities do not exhibit all the features of creativity at equal rate, though it is possible to develop purposefully each of them. Many scholars (Keršenšteiners, 1925; Hibnere, 1998; Lubart \& Georgsdottir, 2004) note that great influence, by stimulating and developing the students' creative activity, can be exerted by a lecturer's personality and the quality of teaching. In his article about Singapore's creative education, Tan indicates the responsibility of teachers:

Teachers must acquire pedagogical competence (e.g., planning lessons, selecting suitable teaching models and managing behaviors). They should process sufficient content knowledge and skills and must be interested in teaching effectively and creatively. In addition, they should also acquire creative skills and techniques, as well as cultivate dispositions related to fostering creativity (Tan, 2004, p. 288).

University teacher's efficient activity is impossible without such elements of pedagogical competence as erudition, fondness for the study course delivered, ability to explain difficult subject matter in plain language. If we want to foster the idea of cultural sustainability through education and especially through teacher education, both university teachers and future teachers' understanding of the aim of education is of a great significance; their current problems and hopes determine the form and content of teachers' individual and professional frameworks (Salìte, 2006).

The development of creative activity of students taps into students' interests, prior knowledge, learning styles, and strategies in an attempt to nurture knowledge construction, perseverance, and intrinsic motivation (Rostan, 2006). Therefore, we would like to characterize the development of students' creative activity as a regular and focused coordinated work of the teacher and students. The university teacher's activity is directed towards the development of the study course content and the use of appropriate teaching methods, which allows for the development of students' interest in creative activity considering both the level of students' artistic qualification and their capabilities to work creatively. Working creatively both under the teacher's guidance and independently, the students develop their creative potential.

The essence of creative activity is not the apparent activity, it is the internal act of creation or creative process. If the students build on their experience, thoroughly analyzing both positive and unsuccessful results of their creative process, their creative activity becomes more productive. Regular analysis of creative process gives the students an opportunity to reach the highest level of creative activity - the level of creativity (Slahova, Cacka, Volonte, \& Savvina, 2007). It means that every creative activity includes the creative process encompassing successive performance of the creative tasks, i.e., the process of creative activity develops according to the specific scheme. 


\section{Model of a creative process}

The creative process is the sequence of thoughts and actions that lead to a novel, adaptive production (Lubart, 2000-2001). Researchers look for common characteristics of all kinds of creative processes in order to develop a general theory of a creative process and creative abilities. Lately it has been acknowledged as the common process that constitutes the basis for all kinds of creative work: the combination of elements in order to gain a new quality and, afterwards, to search for the revelation and the selection of "significant" combinations. The difference is reduced to the difference in an idea. Now we shall elaborate on some conceptions in this direction.

Analysis of theoretical and empirical investigations verifies that the development of a creative process proceeds through several closely interrelated stages. This is a very complex process, depending on different variables and experiences. Experience builds and grows gradually and creativity develops through the specific stages or levels. Several scholars, who have done research on this issue, identify different stages of the creative process and name these stages differently.

The English researcher Wallas (1926), one of the founders of creativity research in education, distinguished between five stages of the creative process:

1. Preparation (preparatory work on a problem that focuses the individual's mind on the problem and explores its dimensions);

2. Incubation (where the problem is internalized into the unconscious mind and nothing appears to be happening externally);

3. Intimation (the creative person gets a 'feeling' that a solution is on its way);

4. Illumination or insight (where the creative idea bursts forth from its preconscious processing into conscious awareness);

5. Verification (where the idea is consciously verified, elaborated, and then applied).

Many scientists (Fontana, 1998; Groborz \& Nęcka, 2003; Lubart, 2000-2001; Mace \& Ward, 2002; Norlander, 2000-2001; Sawyer, 2006; Ландау, 2002) lately have distinguished four stages of the creative activity.

For example, Sawyer (2006) in his research distinguishes and explains the following stages of creative process that are undoubtedly based on the stages by Wallas:

1. Preparation is the initial phase of preliminary work: collecting data and information, searching for related ideas, listening to suggestions.

2. Incubation is the delay between preparation and the moment of insight; during this time the material prepared is internally elaborated and organized.

3. Insight is the subjective experience of having the idea - the "aha" or "eureka" moment.

4. Verification includes two sub-stages: the evaluation of the worth of the insight, and elaboration into its complete form (p. 58).

The mentioned stages are generally accepted by many researchers, sometimes with some variations in title or number of stages. Thus, Osborn (1953) expanded the list to seven stages: 1) orientation (pointing out the problem); 2) preparation (gathering pertinent data); 3) analysis (breaking down the relevant material); 4) ideation (piling up alternatives by way of ideas); 5) incubation ('letting up' to invite illumination); 6) synthesis (putting the pieces together); 7) evaluation (judging the resulting ideas).

The analysis of pedagogical experience while teaching students majoring in art specialities (Slahova, Volonte, Cacka, \& Haw, 2006) confirms the development of 
creative process within the five stages established by Wallas (1926). This division is more relevant and precisely reveals the essence of the creative process of students. For instance, within the study courses in drawing, painting, design, etc. the performance of creative works consists of the tasks to be done in succession, and these tasks correspond to the five stages of creative process characterized above:

1. Emergence of the idea for a work and creation of the first drafts (preparation);

2. Development of drawings, drafts, sketches dealing with the idea put forward in the draft and the design of the future work of art (incubation);

3. Draft in the art technique chosen for the work (intimation);

4. The process of creating a work of art (illumination);

5. Completion of the work and making the last corrections (as well as the design, for example, framing) (verification).

The common principles of the development of the five-stage creative process for the students majoring in Art are presented in the model (see Figure 1). This model is based on the scheme worked out by Mace and Ward (2002, p. 183) and it has been adapted for the work with students under the teacher's guidance. The original model by Mace and Ward consists of four phases or stages: art work conception (1); idea development (2); making the artwork (3); finishing the artwork and resolution (4). Their model has been worked out for artists, and therefore it is natural that it lacks the stage of intimation, which is directed towards the choice of an art technique and material. The stages of our model can be described as follows:

Stage 1: creative beginning (preparation). The stage determines a preliminary analysis of the problem, definition of the idea. The art begins when the idea is still in its uncertainty (Hegel, 1998). Therefore, the preliminary understanding of the artwork is often conceptually vague. The conception of the idea emerges from the theme of the task received, from the interaction of a student's experience in creative activity and outer influence of the teacher during the consultations and communication with course-mates. During this stage the student actively works to create different sketches and compositional drafts of the future creative artwork.

Stage 2: aggregating information and generating ideas (incubation). The stage of incubation does not involve any voluntary intellectual work connected with the definite problem. A person can knowingly deal with other problems or simply relax, taking a rest from this particular problem. On the subconscious level mind continues its work on the problem thus ensuring the emergence of combinations of ideas. Unconscious views reject the majority of these combinations as senseless, but sometimes they also generate promising ideas.

Under favourable conditions, from all the ideas proposed, a person selects one (sometimes two) solution, which best reflects the theme of the task set and contains the elements of novelty and originality. The draft is complemented and improved and the composition of the idea is specified. The idea of the artwork can change any time during the creative process.

Stage 3: creative process of progression (intimation). When the idea has been found, fixed, studied and has found its place in a student's consciousness, there begins a specific process during which the idea attracts whole spectrum of knowledge possessed by the student. All these observations and facts are used for the implementation of idea and are connected with the task. During this stage the artworks may undergo some changes 
aimed at adjustment of the idea. The essence of this stage is that the student looks for and determines the technique to be used in his/her work.

Stage 4: creative technologies (illumination). During this stage of conscious activity the previously approved idea is implemented using the technique and the material selected for the work.

Stage 5: creative result (verification). Exactly during this final stage the artwork is checked for the last time and its relevance is evaluated, the author makes a decision to finish the work, to correct it, or to start a new work in order to implement the same idea.

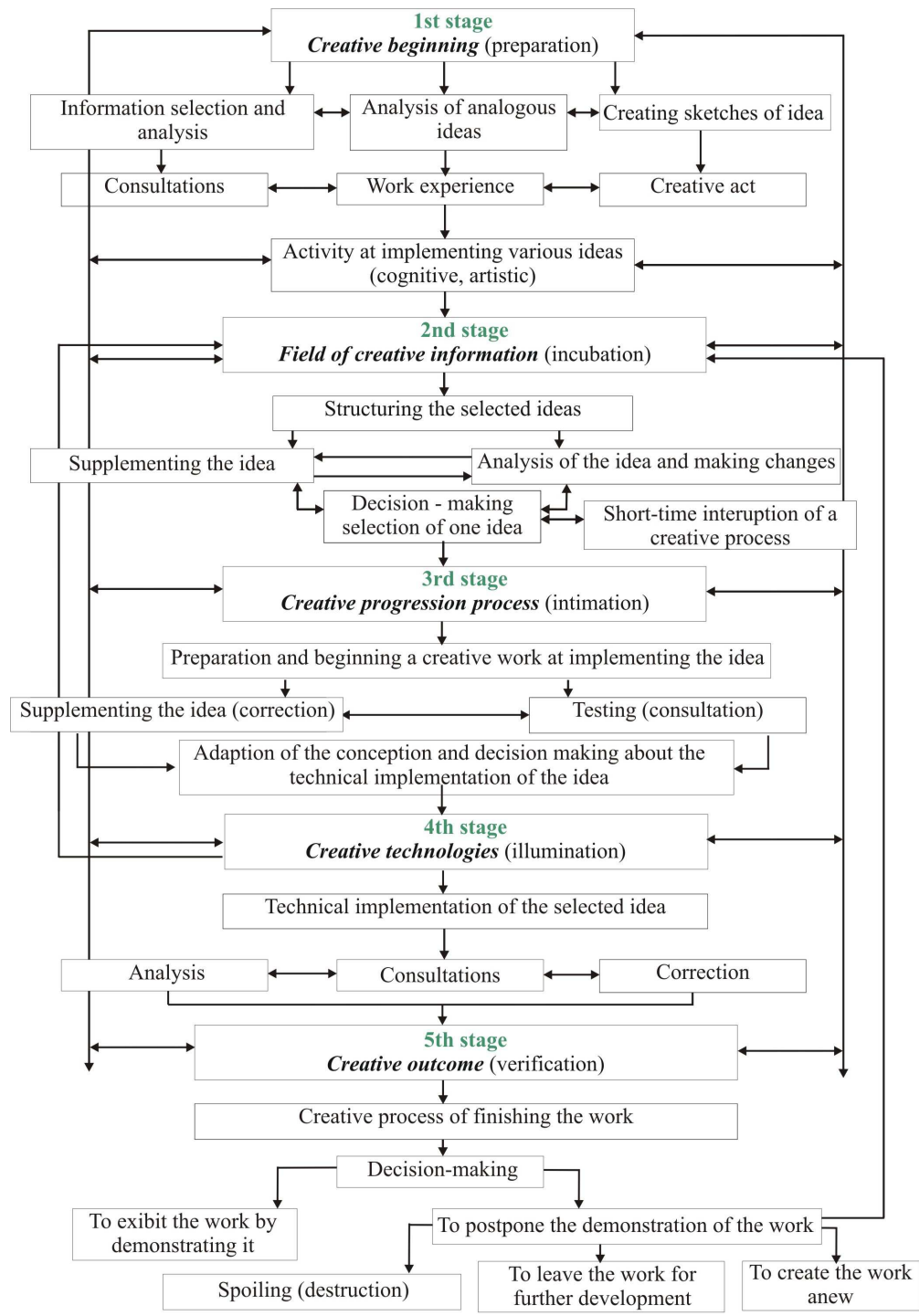

Figure 1. Model of a creative process development for visual art students 
One of the most important features of the model is that it provides a full description of the creative process beginning with the consideration of the idea and ending with the finishing of the work. The model demonstrates that the students' creative potential can be improved at any stage of creative process. These stages, in our opinion, characterize the essence of creative process in a context of sustainable art education the best way.

The teacher guides the students carrying out the creative task during all stages of creative process. The teacher's task in the development of the students' creative activity is to influence their inner world by the help of external stimuli, stirring intellectual, emotional and volitional spheres, i.e., to create an emotional creative environment stimulating the students' eagerness to perform creative works.

During the recent years a number of educational researchers and psychologists (Glück, Ernst, \& Unger, 2002; Groborz \& Nęcka, 2003; Lonergan, Scott, \& Mumford, 2004; Lubart, 2000-2001; Lubart \& Georgsdottir, 2004; VanTassei-Baska, 2006; Кларин, 1995) have turned their attention to the possibilities of the development of the students' creative activity and have proposed various recommendations. In the context of the present research these recommendations have been interpreted for the development of creative activity of the students majoring in Art study programmes:

- To divert internal hurdles from creative manifestations. For the students to be ready for creative search, they have to be encouraged: it is necessary to create the atmosphere of inner freedom and understanding during the practical classes in visual art. Students should not be afraid of making mistakes, presenting all their ideas in produced drafts using different art materials and techniques.

- To pay attention to the work of unconsciousness. Even when the problem is not in the focus of our attention our sub-consciousness might work insensibly. The students must be taught to duly fix the ideas, subjects, and compositions by doing quick drawings, sketches, drafts, which can appear all at once, and so that they could be used when necessary.

- To refrain from evaluation (marks). This condition is especially important at the very beginning of creative activity. The academic tasks in visual art are to be evaluated only on the basis of definite criteria, it is necessary to explain the tasks to be done for the art work beforehand. Evaluating the creative works we should only analyze the level of artistry, and not assess them by marks. Due to these preconditions the students are more open and free in expressing essentially different ideas, not afraid of making mistakes, devoting more time and paying more attention to discussion of the idea generated and of the ways how to implement or present it better.

- To show how to use the analogues (for example, original works). Research of creative process demonstrates that the possibilities of creative search grow if students' own ideas are compared to the existing artistic search, composition and colour development in the works by famous painters. Allowing for imitation of creative behaviour it is necessary to include the tasks to copy the works done by renowned painters in all courses of art; having accomplished the tasks students interpret their own work comparing it with the original.

- To give the possibility to practice. Carrying out small creative tasks develops students' confidence. Such a training of the hand and the eye should take place parallel to the accomplishment of the long-term academic works done at class. 
- "To discipline" imagination and vision. Creating the conditions of inner freedom during the creative process we should review the ideas critically, partially rejecting the compositions that are not so successful.

- To avert inner burdles of thinking. To create such conditions that students would understand (feel) that any idea, sketch of composition or draft is worth of attention and that it will be benevolently analyzed.

- To develop perceptivity, to enlarge the sensitiveness, amplitude and depth of perception. This can be dealt with under the teacher's guidance while developing creative perception. To implement this recommendation more successfully organizing regular meetings with artists, attending museums and galleries, inviting artists to conduct art workshops and to give master classes would be necessary.

- To develop the necessity to use theoretical knowledge in art when implementing the creative tasks. In practical work students put into practice the laws of composition and view, academic fundamentals of drawing and painting, various techniques and artistic materials. The developmental process of creative activity has to take place in the interaction of practical activity and theory.

- To belp to discern the meaning, the general direction of one's creative activity, to be self-aware of ability to deal with creative tasks participating in exhibitions, workshops and other artistic projects. Without such understanding all the exercises stimulating creative activity might be perceived as simple entertainment.

- To teach students to plan and control their creative activity.

- To develop the creative behaviour in the presence of a positive role-model. This recommendation can be observed getting involved in the creative study process and workshops conducted by well-known artists - practitioners.

\section{Conclusion}

One of the professional features of a secondary school teacher of visual art holding a Bachelor degree in Art is his/her ability not only to carry out pedagogical creative work, but also the ability to be involved in creative activity himself/herself. A teacher has to be aware of and develop in himself/herself the value of creative work as the basis of his/her profession, and he/she should feel free doing creative work.

All this makes us review the essence of the educational process of secondary education visual art teachers, where the priority is the development of the prospective teachers' creative activity. Taking it into consideration it is necessary to create such psychological and pedagogical conditions of the study process, that there are no obstacles to creative self-realization.

One of the functions of Art subjects is to bring forward the students' creative abilities and to develop them to the utmost. Favourable conditions for the productive creative activity of every student can be created by the teacher who is competent in the basic aspects of educational psychology and who can be flexible in organization of the development of the students' creative process.

To solve this problem we worked out the model of the development of creative process, that could foster the effectiveness of the students' creative activity. The scientific 
approach used to develop this model is based on the theoretical research and the analysis of pedagogical experience, as well as on the reflection of approved theoretical perspectives of the creative process development.

The aim of the proposed model is to help the students to foster their creative activity when dealing with artistic tasks purposefully and effectively. The stages of the creative process reflected in the model include the succession of students' logical actions that trigger their creative activity. The model of the creative process also presents the structure of every stage and the preconditions that allow for the performance of the creative acts characteristic of the given stage.

The model of creative process is directed towards the sustainability education and reflects objective laws of creative activity and its flexible character. The model can be used not only in work with the prospective art teachers, but also with the students from other study programs, for example, for music teachers or teachers of history of civilization.

The criterion of viability of this model is its practical usefulness. Moreover, the practice allows for adjustment of the model in accordance with the peculiarities of every study course in Art. Therefore the existence of definite examples of its usage is an obligatory precondition for the model of the development of creative process proposed for consideration.

\section{References:}

Glück, J., Ernst, R., \& Unger, F. (2002). How creatives define creativity: Definitions reflect different types of creativity. Creativity Research Journal, 14(1), 55-67. DOI: 10.1207/S15326934CRJ1401_5.

Groborz, M., \& Nęcka, E. (2003). Creativity and cognitive control: Explorations of generation and evaluation skills. Creativity Research Journal, 15(2/3), 183-197.

Hegel, G. W. F. (1998). Philosophy of fine art. In D. Preziosi (Ed.), The art of art history: A critical anthology (pp. 97-109). Oxford: Oxford University Press.

Hibnere, V. (1998). Bèrna vizuālà darbïba. 1. daḷa. Pedagoǵiskā psibologiija [Child's visual activity. Part 1. Pedagogical psychology]. Riga: RaKa.

Fontana, D. (1988). Psychology for teachers ( $2^{\text {nd }}$ ed.). Palgrave Macmillan: Hong Kong. James, K., \& Asmus, C. (2000-2001). Personality, cognitive skills, and creativity in different life domains. Creativity Research Journal, 13(2), 149-159.

Ikere, Z. (2008). Human being as a creative differentiator of the logos of life. In A.-T. Tymieniecka (Ed.), Analecta Husserliana XCV (pp. 9-22). Kluwer Academic Publishers.

Keršenšteiners, G. (1925). Audzinātāja dvēsele un skolotāju izglìtības jautājums [Educator's soul and question of teacher education]. Riga: Izglìtibas Ministrijas izdevums.

Lonergan, D. C., Scott, G. M., \& Mumford, M. D. (2004). Evaluative aspects of creative thought: Effects of appraisal and revision standards. Creativity Research Journal, 16(2/3), 231-246. DOI: 10.1207/s15326934crj1602\&3_7.

Lubart, T. I. (2000-2001). Models of the creative process: Past, present and future. Creativity Research Journal, 13(3/4), 295-308. 
Lubart, T. I., \& Georgsdottir, A. (2004). Creativity: Developmental and cross-cultural issues. In S. Lau, A. N. N. Hui \& G. Y. C. Ng (Eds.), Creativity: When East meets West (pp. 23-54). World Scientific Publishing Co Pte Ltd.

Mace, M.-A., \& Ward, T. (2002). Modelling the creative process: A Grounded Theory Analysis of creativity in the domain of art making. Creativity Research Journal, 14(2), 179-192.

Mumford, M. D. (2003). Where have we been, where are we going? Taking stock in creativity research. Creativity Research Journal, 15(2/3), 107-120. DOI: 10.1207/ S15326934CRJ152\&3_01.

Norlander, T. (2000-2001). Conceptual convergence in creativity: Incubation and brain disease state. Creativity Research Journal, 13(3/4), 329-333. DOI: 10.1207/S 15326934CRJ1334_10.

Osborn, A. (1953). Applied imagination. New York: Charles Scribner.

Rostan, S. M. (2006). A young artist's story: Advancing knowledge and the development of artistic talent and creativity in children. In J. C. Kaufman \& J. Baer (Eds.), Creative and reason in cognitive development (pp. 244-268). Cambridge University Press. DOI: 10.2277/0521605040.

Salite, I. (2006). Aim of education in the context of present and future educational issues: Perspective of teachers. In A. Pipere (Ed.), Education and sustainable development: First steps toward changes (Vol. 1, pp. 390-411). Daugavpils University: Saule.

Salìte, I., Mičule, I., Kravale, M., Iliško, D., \& Stakle, A. (2007). Toward the sustainability in teacher education: Promise of action research. In A. Pipere (Ed.), Education and sustainable development: First steps toward changes (Vol. 2, pp. 263-292). Daugavpils University: Saule.

Sawyer, K. R. (2006). Explaining creativity. The science of human innovation. Oxford University Press.

Slahova, A., Savvina, J., Cacka, M., \& Volonte, I. (2007). Creative activity in conception of sustainable development education. International Journal of Sustainability in Higher Education, 8(2), 142-154. DOI: 10.1108/14676370710726616.

Slahova, A., Volonte, I., Cacka, M., \& Haw, R. B. H. (2006). Evaluation aspects of creative process. In A. Pipere (Ed.), Education and sustainable development: First steps toward changes (Vol. 1, pp. 149-167). Daugavpils University: Saule.

Tan, A.-G. (2004). Singapure's creativity education: A framework of fostering constructive creativity. In S. Lau, A. N. N. Hui \& G. Y. C. Ng (Eds.), Creativity: When East meets West (pp. 277-304). World Scientific Publishing Co Pte Ltd.

UNESCO. (1998). UN World Declaration on higher education for the twenty-first century: Vision and action. Article 9: Innovative educational approaches: Critical thinking and creativity. Retrieved February 13, 2008, from http://www.unesco.org/ education/educprog/wche/declaration eng.htm

VanTassei-Baska, J. (2006). Higher level thinking in gifted education. In J. C. Kaufman \& J. Baer (Eds.), Creativity and reason in cognitive development (pp. 297-315). Cambridge University Press. DOI: 10.2277/0521605040.

Varzim, M. (2005). Creativity - stimulus for human development. In R. Urniežus (Ed.), Kürybos erdves [The spaces of creation] (Vol.2, pp. 110-115). Lithuania: Shiauliai University. 
Wallas, G. (1926). The art of thought. New York: Harcourt, Brace and Company.

Вишнякова Н. Ф. (1995). Креативная психопедагогика. Психология творческого обучения [Creative psycho-pedagogy. Psychology of creative training]. Минск.

Кларин М. В. (1995). Инновации в мировой педагогике: Обучение на основе исследования, игры и дискуссии (анализ зарубежного опыта) [Innovations in world pedagogy: Training on the basis of research, games and discussions]. Рига: НПЦ «Эксперимент».

Кривцун О. А. (1997). Эстетика как психология искусства [Aesthetics as psychology of art]. Москва: Российский государственный гуманитарный университет.

Ландау Э. (2002). Одаренность требует мужества: Психологическое сопровождение одаренного ребенка [Endowment demands courage: Psychological support of the gifted child] (пер. с нем.). Москва: Академия.

Тюрин П.Т. (2001) Введение в психологию дизайнерского творчества [Introduction in Psychology of Design Creativity]. Рига: JUMI.

\section{Correspondence:}

Dr Aleksandra Šlahova, Faculty of Music and Art, Daugavpils University, Saules 1/3, Daugavpils, LV-5400, Latvia. Email: aleksandra.slahova@du.lv

Received 7 January 2009; revised version received 11 March 2009 